Risma, Farida, Siska Andriani

Android Mobile Learning: MIT App Inventor Dan Pengembangannya Pada Pembelajaran Matematika

\title{
Android Mobile Learning: MIT App Inventor Dan Pengembangannya Pada Pembelajaran Matematika
}

\author{
Risma $^{* 1}$, Farida ${ }^{2}$, Siska Andriani ${ }^{3}$ \\ ${ }^{1,2,3}$ Program Studi Pendidikan Matematika, Universitas Islam Negeri Raden Intan Lampung, Indonesia \\ *rismalampung9933@gmail.com
}

\begin{abstract}
ABSTRAK
Penelitian ini bertujuan untuk mengembangkan media pembelajaran matematika mobile learning dengan menggunakan App Inventor 2. Pengembangan menggunakan App Inventor 2 akan memberikan kemudahan untuk mengakses pembelajaran karena aplikasi ini bersifat android. Prosedur pengembangan yang akan dilakukan penulis yaitu menggunakan 4D. Teknik pengumpulan data yang saya gunakan adalah wawancara, angket dan tes. Teknik pengolahan data yang saya gunakan adalah effect size test. Hasil dari penelitian ini adalah sebuah produk yaitu mobile learning yang mengacu pada desain penelitian dan pengembangan yang dimodifikasi dari model pengembangan 4D. Dari hasil penelitian penggunaan mobile learning dengan App Inventor 2 hasil belajar peserta didik lebih meningkat dari sebelumnya. App Inventor 2 adalah aplikasi yang dapat diakses dimana saja dan kapanpun hal tersebut sangat membantu peserta didik belajar memahami materi terlebih dahulu sebelum diperlajari dikelas. Sehingga dapat disimpulkan bahwa media yang dikembangkan penulis layak dan efektif untuk digunakan sebagai bahan ajar untuk membantu peserta didik dalam proses pembelajaran.
\end{abstract}

Kata kunci: Media Pembelajaran, Mobile Learning, App Inventor

\begin{abstract}
This study aims to develop mobile mathematics learning media using App Inventor 2. Development using App Inventor 2 will make it easy to access learning because this application is android in nature. The development procedure that will be carried out by the author is using 4D. The data collection techniques I use are interviews, questionnaires and tests. The data processing technique I use is the effect size test. The result of this research is a product, namely mobile learning, which refers to the modified research and development design of the 4D development model. From the results of research using mobile learning with App Inventor 2 student learning outcomes have increased more than before. App Inventor 2 is an application that can be accessed anywhere and anytime it really helps students learn to understand the material first before being taught in class. So, it can be concluded that the media developed by the author is feasible and effective to be used as teaching material to help students in the learning process.
\end{abstract}

Keywords: learning media, mobile learning, App Inventor

Received: 2020-10-13 ～/Accepted: 2021-04-20

/Published: 2021-05-01

\section{Pendahuluan}

Pembelajaran adalah usaha guru untuk mengarahkan dan membimbing proses belajar peserta didik. dengan sumber belajarnya untuk mencapai tujuan pembelajaran yang diharapkan. Matematika adalah pembelajaran yang penting di jenjang pendidikan dasar sampai dengan pendidikan perguruan tinggi. Untuk mencapai suatu tujuan pembelajaran matematika yang diinginkan tentunya harus memiliki fasilitas, materi, motivasi dan kreatifitas dalam proses pembelajaran (Sartika \& Makmur, 2020; Srimaya, 2017). Mata pelajaran matematika diharapkan tidak hanya membekali peserta didik dengan kemampuan menggunakan perhitungan atau rumus dalam mengerjakan soal, akan tetapi mampu melibatkan kemampuan bernalar matematika dan analisis matematika dalam memecahkan masalah sehari-hari (Muhammad Masyuri Irham, 2020). Paradigma dalam pembelajaran matematika membawa dampak pada penekanan pada perubahan peserta didik dalam proses pembelajaran (Avianty \& Cipta, 2018). Sehingga fokus paradigma pendidikan matematika di dunia telah berubah dan 
matematika itu memiliki peranan penting yang besar dalam kehidupan (Rahmadi, 2015 ; Sari, 2016).

Merujuk tujuan utama pelajaran matematika yaitu peserta didik mampu mengaplikasikan matematika ke dalam kehidupan sehari-hari serta dalam berbagai ilmu pengetahuan, guna mempersiapkan dan meningkatkan kualitas sumber daya manusia (Putri, Parmiti, \& Sudarma, 2017). Harapannya, para pendidik dapat mewujudkan tujuan pembelajaran matematika dengan baik dan maksimal. Namun untuk mewujudkan pembelajaran Matematika yang baik, banyak sekali permasalahan yang harus diselesaikan (Holidun, Masykur, Suherman, \& Putra, 2018; Khoiriyah \& Rizki, 2017). Seperti penggunaan pembelajaran langsung yang selalu diterapkan kepada peserta didik. Selain itu pembelajaran matematika terkesan monoton dan kurang kreatif dikarekan teknik pembelajaran yang kurang bervariasi dan minim digunakan media belajar (Masykur, Nofrizal, \& Syazali, 2017).

Melihat era teknologi yang ada masa kini, sudah seharusnya proses penyampaian materi pendidikan kepada peserta didik yang dilakukan secara sistematis oleh guru atau yang sering disebut dengan pembelajaran metode langsung sudah kurang relevan. Menurut Irwandani (2016) dalam penelitiannya menyampaikan bahwa peserta didik yang selalu disuguhi dengan metode pembelajaran langsung kurang maksimal dan membuat peserta didik terasa jenuh. Oleh karena itu, diperlukan media pembelajaran yang bersifat mandiri yang dapat membuat pembelajaran lebih menarik. Dari permasalahan yang diperoleh terkait pembelajaran matematika penulis tertarik melakukan sebuah penelitian dengan menggunakan sebuah media pembelajaran matematika guna mengatasi kejenuhan dan kebosanan peserta didik.

Penulis akan mengembangkan bahan ajar dengan memanfaatkan kehadiran smartphone sebagai bahan ajar matematika. Penelitian yang telah dilakukan Chusni, Zakwandi, Aulia, Alawiyah, \& Ariandini (2018) media pembelajaran mobile learning mampu meningkatkan kemampuan koneksi matematis sebanyak 85,4\% dari peserta didik. Menurut Setyadi (2017) media pembelajaran berbasis mobile learning sangat berperan dalam melatih peserta didik mengerjakan soal. Menurut Surahman \& Surjono (2017) pembelajaran dengan menggunakan adaptive mobile learning sangat efektif dalam membantu peserta didik mencapai tujuan pembelajaran biologi secara efesien. Menurut Maharani, Supriadi, \& Widiyastuti, (2018) dalam penelitiannya mengungkapkan bahwa media pembelajaran yang besifat mandiri mampu menurunkan kecemasan peserta didik dalam belajar matematika.

Penelitian terdahulu yang telah dipaparkan dapat disimpulkan bahwa penggunaan media pembelajaran berbasis mobile learning mampu memecahkan permasalah dalam pembelajaran khususnya matematika. Namun dari penelitian diatas yang telah dilakukan pengembangan adalah dalam mata pelajaran lain bukan matematika. Selain itu media yang telah dikembangkan menggunakan software adobe flash dan contruct 2. Kehadiran penulisan ini akan memberikan keterbaharuan tentunya akan lebih mudah dalam pengembangannya yaitu penulis menggunakan aplikasi App Inventor 2 (AI2. App Inventor 2 (AI2) adalah aplikasi web sumber terbuka yang awalnya dikembangkan oleh Google, dan saat ini dikelola oleh Massachusetts Institute of Technology (MIT). App Inventor merupakan sebuah pemograman yang menghasilkan aplikasi yang dapat digunakan di sistem Android. AI2 berbasis cloud yang diakses menggunakan internet browser (Sumilat, 2018). Sehingga penulisan ini bertujuan untuk mengembangkan android mobile learning matematika dengan menggunakan App Inventor 2 
yang dapat memberikan pembelajaran secara mandiri untuk peserta didik lebih memahami materi matematika.

\section{Metode Penelitian}

Metode yang akan digunakan dalam penulisan ini adalah pengembangan yaitu prosedur 4D (difine, design, development and disseminate). Berikut ini gambar 1 bagan prosedur 4D:

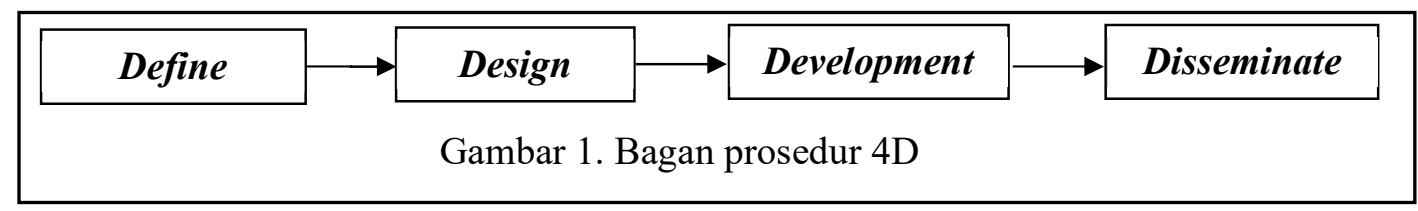

Teknik pengumpulan data yang digunakan penulis adalah wawancara, penyebaran angket dan tes. Angket yang digunakan adalah angket validasi kepada para pakar ahli dan angket peserta didik. Adapun data kualitatif dihasilkan dari saran dan masukan para pakar ahli sedangkan data kuantitatif dihasilkan dari hasil validasi dan tes yang telah dilakukan. Menentukan kriteria kelayakan dari hasil skor para ahli validator dan skor angket peserta didik menggunakan tabel skala likert sebagai berikut (Kurniasari et al., 2018):

Tabel 1. Kriteria Validasi dan Angket (dimodifikasi)

\begin{tabular}{ccc}
\hline Skor Kualitas & Kriteria Validasi & Kriteria Angket \\
\hline $3,26<\bar{x} \leq 4,00$ & Valid & Sangat Menarik \\
$2,51<\bar{x} \leq 3,26$ & Cukup Valid & Menarik \\
$1,76<\bar{x} \leq 2,51$ & Kurang Valid & Kurang Menarik \\
$1,00<\bar{x} \leq 1,76$ & Tidak Valid & Sangat tidak Menarik \\
\hline
\end{tabular}

Tabel 1 kriteria validasi dan angket yang digunakan untuk menghitung hasil skor validasi dan hasil skor angket dari produk mobile learning dengan App Inventor 2 memiliki skor kualitas $3,26<\bar{x} \leq 4,00$ dengan kriteria validasi "valid" dan kriteria angket "sangat menarik" apabila menadapatkan skor tersebut maka modul yang dikembangkan layak digunakan dalam proses pembelajaran tanpa revisi. Teknik pengolahan data yang digunakan dalam pengolahan data hasil tes adalah teknik uji effect size.

\section{Hasil dan Pembahasan}

Penelitian dan pengembangan dalam penulisan ini menghasilkan sebuah media pembelajaran matematika berupa Mobile Learning yang dikembangkan menggunakan model 4D yaitu tahap pendefinisian (define), tahap perancangan (design), tahap pengembangan (development), dan tahap penyebaran (dessimate).

Tahap pertama dilakukan pendefinisian analisis awal tentang kebutuhan dan potensi yang dapat dimanfaatkan dizaman kemajuan teknologi yang ada pada era kini. Berdasarkan hasil angket yang telah disebar di UIN Radeen Intan Lampung, STKIP PGRI Bandar Lampung, dan UM Metro pada jurusan pendidikan matematika belum pernah digunakan pembelajaran dengan memanfaatkan kehadirannya smartphone. Menurut Oktiana (2015) mempermudah peserta didik dalam mengakses pembelajaran dimanapun dan kapanpun mereka berada tanpa harus 


\section{AlphaMath \\ Journal of Mathematics Education, 7(1) May 2021}

membawa modul cetak. Selain itu menurut Saputra, Abidin, Ansari, \& Hidayat (2018) smartphone (android) dapat dimanfaatkan peserta didik dalam hal yang positif seperti digunakan untuk pembelajaran. Berdasarkan hasil wawancara diperoleh bahwa proses pembelajaran Dasar-Dasar logika matematika mereka masih menggunakan modul cetak dan media pembelajaran yang mendukung pembelajaran hanya power point dalam hal ini menjadikan pembelajaran monoton. Menurut Masykur, Nofrizal, \& Syazali (2017) pembelajaran yang monton dapat membuat peserta didik jenuh dan bosan sehingga memberikan peserta didik mengeluarkan asumsi pembelajaran matematika itu sulit. Disisi lain peserta didik sudah rata-rata menggunakan android (smartphone) sehingga hal ini sebuah potensi yang dapat dimanfaatkan sebagai media pembelajaran dalam rangka mengatasi pembelajaran yang monoton. Pengembangannya yang dilakukan oleh penulis adalah mengembangkan media pembelajaran matematika berupa Mobile Learning menggunakan Mit App Inventor karena akan memberikan inovasi baru dalam proses pembelajaran untuk materi Dasar-Dasar Logika Matematika dan memberikan kemudahan bagi dosen dan mahapeserta didik.

Setelah didapatkan masalah dan potensi yang dapat dimanfaatkan selanjutnya dilakukan tahap kedua yaitu perancangan.Perancangan dilakukan bertujuan untuk merancang media pembelajaran untuk memperoleh draft awal. Media akan dikembangkan menggunakan aplikasi Mit App Inventor. Pertimbangan penulis memilih Mit App Inventor mudah untuk pembuatannya untuk para pemula pembuatan software karena tidak menggunakan bahasa pemograman.

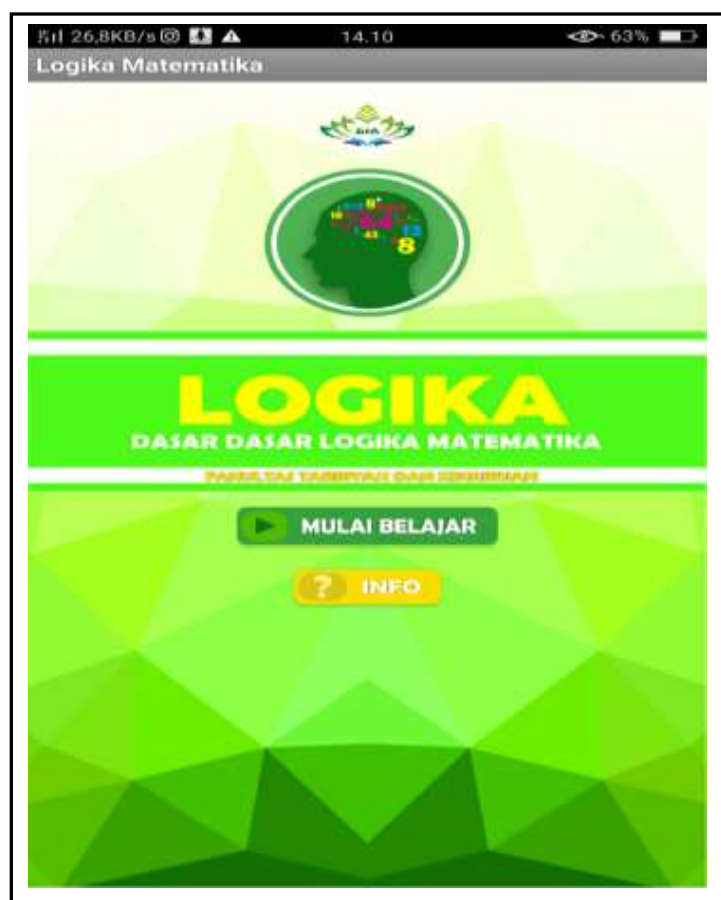

Gambar 2. Tampilan awal media

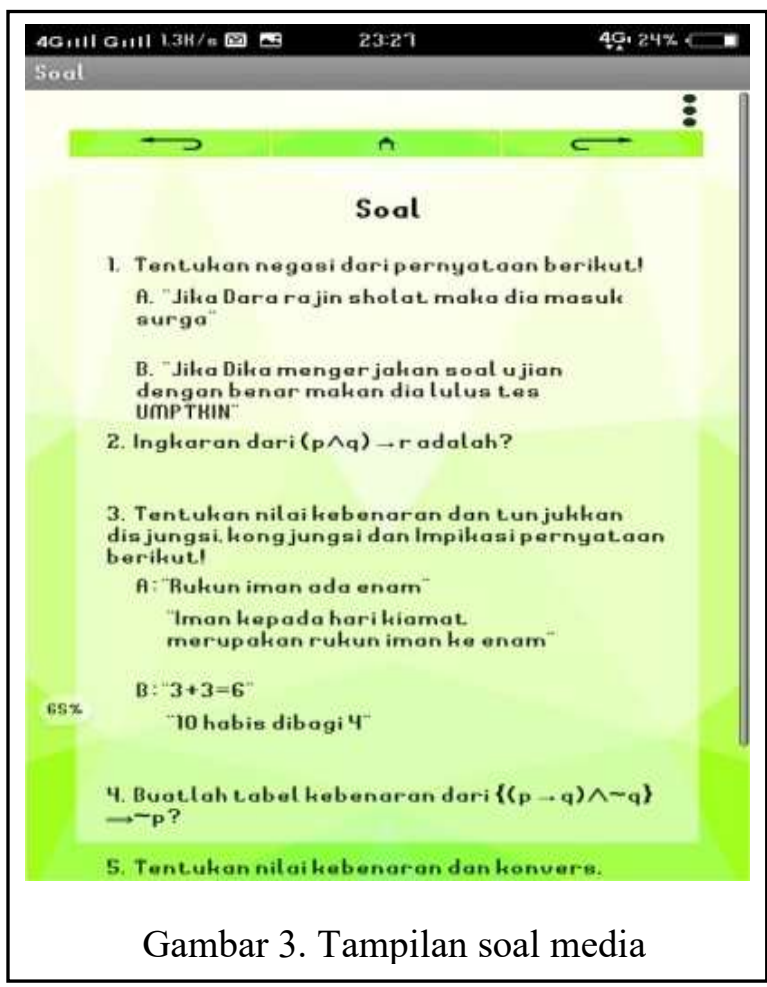

Setelah media didesain selanjutnya dilakukan tahap penilaian kelayakan media. Kelayakan media di validasikan kepada para pakar ahli yaitu 3 ahli materi dan 2 ahli media. Hasil validasi dapat dilihat pada tabel berikut. 
Tabel 2. Hasil validasi ahli materi tahap 1

\begin{tabular}{lcl}
\hline \multicolumn{1}{c}{ Aspek } & Skor & Keterangan \\
\hline Kesesuaian materi & 3 & Cukup valid \\
Keakuratan materi & 3,17 & Cukup valid \\
Mendorong keingintahuan & 3 & Cukup valid \\
Kesesuaian penyajian & 3,1 & Cukup valid \\
Bahasa & 3,1 & Cukup valid \\
\hline
\end{tabular}

Tabel 3. Hasil validasi ahli media tahap 1

\begin{tabular}{lcc}
\hline \multicolumn{1}{c}{ Aspek } & Skor & Keterangan \\
\hline Efesiensi media & 3,1 & Cukup valid \\
Fungsi tombol & 2,75 & Cukup valid \\
Grafis & 2,5 & Cukup valid \\
\hline
\end{tabular}

Berdasarkan tabel 2 dan 3 hasil validasi awal oleh ahli materi dan ahli media diperoleh skor rata-rata pada kriteria cukup valid. Hal ini berarti media belum layak untuk digunakan dan dilakukan uji coba lapangan.Sehingga media diperbaiki kembali, perbaikan dilakukan sesuai dengan masukan dan saran para ahli. Beberapa perbaikan dilakukan diantaranya sebagai berikut.

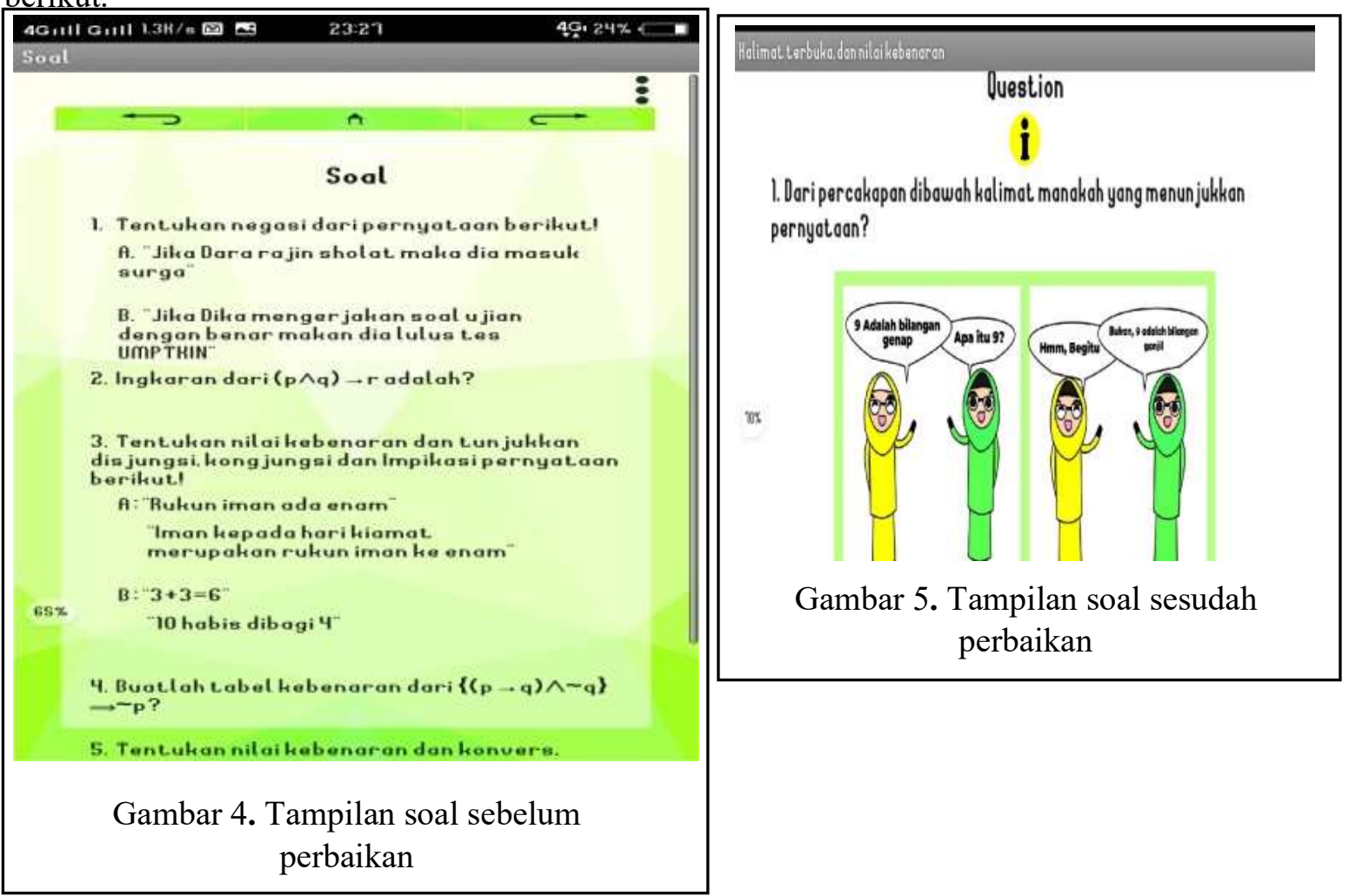

Gambar 5 di atas perbaikan dilakukan dengan membuat soal dengan ilustrasi percakapan kehidupan sehari-hari, sebelum perbaikan soal tidak menggunakan ilustrasi percakapan kehidupan sehari-hari dan setelah mendapatkan saran dari ahli materi maka soal dibuat dengan ilustrasi percakapan kehidupan sehari-hari. Setelah media diperbaiki sesuai dengan saran dan masukan para ahli maka selanjutnya media divalidasikan kembali. Hasil validasi tahap 2 adalah sebagai berikut. 
Tabel 4. Hasil validasi ahli materi tahap 2

\begin{tabular}{lcc}
\hline \multicolumn{1}{c}{ Aspek } & Skor & Keterangan \\
\hline Kesesuaian materi & 3,5 & Valid \\
Keakuratan materi & 3,75 & Valid \\
Mendorong keingintahuan & 3,6 & Valid \\
Kesesuaian penyajian & 3,5 & Valid \\
Bahasa & 3,6 & Valid \\
\hline
\end{tabular}

Tabel 5. Hasil validasi ahli media tahap 1

\begin{tabular}{lcc}
\hline \multicolumn{1}{c}{ Aspek } & Skor & Keterangan \\
\hline Efesiensi media & 3,5 & Valid \\
Fungsi tombol & 3,5 & Valid \\
Grafis & 3,4 & Valid \\
\hline
\end{tabular}

Berdasarkan hasil validasi kedua, hasil validasi diperoleh skor rata-rata pada kriteria valid, sehingga disimpulkan bahwa media sudah layak digunakan sebagai bahan ajar dan dapat dilakukan uji coba lapangan. Menurut Sari, Farida, \& Syazali (2016) media yang telah dikembangkan mendapatkan kevalidan dari para ahli dapat dilakukan uji coba produk kepada peserta didik. Seperti yang telah dijelaskan Sari, Farida, \& Putra (2017) media pembelajaran yang telah dikembangkan tidak hanya cukup dengan kelayakan media saja, tetapi juga kemenarikan oleh peserta didik. Sehingga dilakukan uji coba produk media kepada peserta didik dalam rangka melihat respon terhadap penggunaan media yang sudah dikembangkan.

Uji coba produk dilakukan dengan menggunakan tes sebelum memulai pembelajaran dan sesudah melakukan pembelajaran dengan media yang dikembangkan atau yang disebut Pretest dan Posttest. Tes dilakukan pada 2 skala berbeda yaitu skala besar dan skala kecil. Skala kecil dilakukan uji coba dalam 2 kelas yang masing-masing kelas terdiri dari 10 peserta didik. Hasil uji coba pada skala kecil dari 2 kelas diperoleh skor rata-rata 3,49 dengan kriteria sangat menarik. Sedangkan uji pada skala besar dengan 30 responden pada semester IVdan 28 responden pada semester II diperoleh hasil uji coba dengan skor rata-rata dari 2 kelas 3,55 pada kriteria sangat menarik. Berdasarkan hasil uji kemenarikan media diatas maka disimpulkan media yang sudah dikembangkan sangat menarik untuk digunakan dalam proses pembelajaran matematika. Selanjutnya dilakukan uji efektifitas dengan uji effect size. Uji keefektifan ini dilakukan kepada 2 kelas pada prodi pendidikan matematika UIN Raden Intan Lampung.

Tabel 6. Data Hasil Perhitungan Pretest dan Posttest II A

\begin{tabular}{cccccc}
\hline & $\mathrm{n}$ & $\begin{array}{c}\text { Skor } \\
\text { Maksimum }\end{array}$ & $\begin{array}{c}\text { Skor } \\
\text { Minimum }\end{array}$ & Rata-Rata & $\begin{array}{c}\text { Standar } \\
\text { Deviasi }\end{array}$ \\
\hline Pretest & 28 & 60 & 20 & 43,21 & 43,80 \\
Posttest & 28 & 90 & 50 & 70,17 & 69,81 \\
\hline
\end{tabular}

Tabel 7. Data Hasil Perhitungan Pretest dan Posttest IV C

\begin{tabular}{cccccc}
\hline & $\mathrm{n}$ & $\begin{array}{c}\text { Skor } \\
\text { Maksimum }\end{array}$ & $\begin{array}{c}\text { Skor } \\
\text { Minimum }\end{array}$ & Rata-Rata & $\begin{array}{c}\text { Standar } \\
\text { Deviasi }\end{array}$ \\
\hline Pretest & 30 & 70 & 15 & 33,67 & 36,39 \\
Posttest & 30 & 100 & 45 & 63,3 & 65,11 \\
\hline
\end{tabular}


Berdasarkan tabel 6 dan 7 hasil analisis data menunjukkan bahwa rata-rata nilai pretest lebih kecil dari hasil rata-rata nilai posttest begitu pula dengan hasil standar deviasi nilai pretest dan posttest, untuk itu uji effect size dapat dilakukan. Hasil pengujian hipotesis disimpulkan $E_{s}=0,46$ pada semester II dan $E_{s}=0,56$ pada semester IV dengan kategori sedang.Sehingga rata-rata tes hasil belajar peserta didik sesudah menggunakan mobilelearning lebih tinggi dari rata-rata kemampuan hasil belajar peserta didik sebelum memakai mobile-learning, dari kesimpulan tersebut menunjukkan bahwa mobile-learning dapat meningkatkan kemampuan hasil belajar peserta didik. Penelitian ini menciptakan mobilelearning, pendidik sebagai pengajar mampu menciptakan pembelajaran aktif, kreatif dan inovatif, karena tidak dapat dipungkiri, tujuan pembelajaran yang sesungguhnya adalah menggunakan bahan ajar yang tepat dan bervariasi dalam proses pembelajaran sehingga dapat mengurangi sikap pasif mahasiswa.

Berdasarkan hasil penelitian yang telah diperoleh adalah media mobile learning yang dikembangkan valid dan praktis. Hasil uji coba terhadap mahasiswa menunjukkan bahwa media mampu meningkatkan hasil belajar dilihat dari hasil pretest dan posttest yang menunjukkan nilai signifikan. Hal ini sejalan dengan hasil penelitian (Rachma et al., 2020) Mobile learning mampu meningkatkan hasil belajar siswa dan membantu siswa memahami bentuk dan ruang pada materi Bangun Ruang Sisi Lengkung. Penggunaan Mobile learning dalam pembelajaran menjadi tambahan pembelajaran matematika yang dapat diakses dimanapun dan kapanpun (Apriyanto \& Hilmi, 2019). Dari penelitian yang dilakukan (Ningsih \& Adesti, 2019) kelayakan mobile learning berbasis android pada mata kuliah strategi pembelajaran dengan kriteria valid dan praktis.

Kelebihan dari media yang dikembangkan adalah memiliki tampilan yang menarik, dapat digunakan dimana dan kapan saja tanpa terhubung dengan internet, Mobile learning dapat diinstal di semua smartphone, memberikan fokus pada pembelajaran materi logika untuk mahasiswa. Namun demikian, masih terdapat kekurangan seperti rumus atau tulisan yang penting tidak diperjelas, media belum dapat didownload di playstore.

\section{Simpulan}

Hasil penelitian dan pengembangan yang telah dibahas maka disimpulkan bahwa penelitian dan pengembangan ini menghasilkan sebuah produk yakni Mobile-Learning yang mengacu pada rancangan penelitian dan pengembangan yang dimodifikasi dari model pengembangan 4D. Materi yang dibahas pada media ini adalah Dasar-Dasar Logika. Berdasarkan hasil angket validasi dan respon peserta didik mengenai kelayakan dan kemenarikan Mobile-Learning diperolah rata-rata 3,59 oleh ahli materi, dan 3,46 oleh ahli media sedangkan hasil angket respon peserta didik skala kecil diperoleh rata-rata 3,49 dan pada skala besar diperoleh ratarata 3,55 dengan kriteria sangat menarik. Berdasarkan hasil uji effect size dikelas IV $\mathrm{C}$ diperoleh $E_{S}=0,56$, dan hasil uji effect size dikelas II A diperoleh $E_{S}=0,65$. Dari kedua data tersebut menunjukkan bahwa media mobile learning yang dikembangkan layak dan efektif digunakan sebagai bahan ajar untuk membantu peserta didik dalam proses pembelajaran.

\section{Daftar Pustaka}

Apriyanto, M. T., \& Hilmi, R. A. (2019). Media Pembelajaran Matematika (Mobile Learning) Berbasis Android. Seminar Nasional Penelitian Pendidikan Matematika (SNP2M), 115124.

Avianty, D., \& Cipta, D. A. S. (2018). Pengembangan Multimedia Interaktif Berbasis Masalah 
Untuk Mendayagunakan Kemampuan Berpikir Tingkat Tinggi Pada Peserta didik Sekolah Dasar. AKSIOMA: Jurnal Program Studi Pendidikan Matematika, 7(2), 237. https://doi.org/10.24127/ajpm.v7i2.1503

Chusni, M. M., Zakwandi, R., Aulia, M. R., Alawiyah, T. A., \& Ariandini, S. (2018). Pelatihan Rancang Bangun Media Pembelajaran Mobile Learning Berbasis Android Untuk Meningkatkan Kompetensi Pedagogik Guru Madrasah.Jurnal Al-Khidmat, 1(1), 67-72.

Hamdi, S., \& Abadi, A. M. (2014). Pengaruh motivasi, self-efficacy dan latar belakang pendidikan terhadap prestasi matematika peserta didik PGSD STKIP-H dan PGMI IAIH. Jurnal Riset Pendidikan Matematika, 1(1), 77-87.

Holidun, H., Masykur, R., Suherman, S., \& Putra, F. G. (2018). Kemampuan Pemecahan Masalah Matematis Kelompok Matematika Ilmu Alam dan Ilmu-Ilmu Sosial. Desimal: Jurnal Matematika, 1(1), 29-37.

Irham, Muhammad Masyuri. (2020). Pengaruh Pembelajaran Realistic Mathematic Education Terhadap Kemampuan Literasi Dan Disposisi Matematis Di SMP Negeri 4 Randudongkal. AlphaMath : Journal of Mathematics Education, 6, 55-61.

Irwandani, I. (2016). Potensi Media Sosial dalam Mempopulerkan Konten Sains Islam. Tadris: Jurnal Keguruan dan Ilmu Tarbiyah, 1(2), 173-177.

Khoiriyah, U., \& Rizki, S. (2017). Pengembangan Bahan Ajar Himpunan Matematika Yang Dikaitkan Dengan Nilai-Nilai Islam. AKSIOMA: Jurnal Program Studi Pendidikan Matematika, 6(3), 315. https://doi.org/10.24127/ajpm.v6i3.1142

Kurniasari, I., M, R. R., \& Fakhri, J. (2018). DEVELOPMENT OF E-MODULE ESTABLISHING ETHNOMATHEMATICS IN BUILDING ROAD SIDE MATERIAL. Indonesian Journal Of Science and Mathematics Education, 01(November), 227-235.

Maharani, M., Supriadi, N., \& Widiyastuti, R. (2018). Media Pembelajaran Matematika Berbasis Kartun untuk Menurunkan Kecemasan Peserta didik. Desimal: Jurnal Matematika, 1(1), 101-106.

Masykur, R., Nofrizal, N., \& Syazali, M. (2017). Pengembangan Media Pembelajaran Matematika dengan Macromedia Flash. Al-Jabar : Jurnal Pendidikan Matematika, 8(2), 177-186. https://doi.org/10.24042/ajpm.v8i2.2014

Ningsih, S., \& Adesti, A. (2019). Pengembangan Mobile Learning Berbasis Android pada Mata Kuliah Strategi Pembelajaran Universitas Baturaja. Edcomtech : Jurnal Kajian Teknologi Pendidikan, 2, 163-172.

Rachma, Y. P., Setyadi, D., \& Mampauw, H. L. (2020). Pengembangan Mobile Learning Barusikung Berbasis Android pada Materi Bangun Ruang Sisi Lengkung. Mosharafa: Jurnal Pendidikan Matematika, 9(September).

Sari, A. U., Farida, F., \& Putra, F. G. (2017). Pengembangan media pembelajaran berbantuan web dengan pendekatan etnomatematika pada pokok bahasan bangun ruang sisi datar. Prosiding Seminar Nasional Matematika dan Pendidikan Matematika, 1(1), 209-214.

Sari, W. R. (2016). Pengembangan perangkat pembelajaran bangun ruang di SMP dengan pendekatan pendidikan matematika realistik. Jurnal Riset Pendidikan Matematika, 3(1), $109-121$.

Sartika, I., \& Makmur, A. (2020). Pengembangan Moodul Pembelajaran Matematika Berbasis Etnomatematika Menggunakan Metode Discovery. PeTeKa (Jurnal Penelitian Tindakan Kelas Dan Pengembangan Pembelajaran), 3, 122-126.

Srimaya. (2017). Efektivitas Media Pembelajaran Power Point untuk Meningkatkan Motivasi dan Hasil Belajar Biologi Siswa. Jurnal Biotek, 5(1), 53-68. http://journal.uinalauddin.ac.id/index.php/biotek/article/view/3446 
Setyadi, D. (2017). Pengembangan mobile learning berbasis android sebagai sarana berlatih mengerjakan soal matematika. Satya Widya, 33(2), 87-92.

Sumilat, J. M. (2018). Pemanfaatan Media Pembelajaran Matematika Interaktif Untuk Meningkatkan Hasil Belajar Peserta didik di SD Negeri 2 Tataaran. Jurnal Inventa, 2(1), 40-46.

Surahman, E., \& Surjono, H. D. (2017). Pengembangan adaptive mobile learning pada mata pelajaran biologi SMA sebagai up/aya mendukung proses blended learning. Jurnal Inovasi Teknologi Pendidikan, 4(1), 26-37. 